\title{
PHYSIOLOGICAL ROLE OF BLOOD PLASMA INSULIN LIKE GROWTH FACTOR- 1 AND PROLACTIN IN LACTATING OF PRIMIPAROUS EGYPTIAN BUFFALOES
}

\author{
M. El-Khashab, A. Rohayem, A. Haider and A. Abdel-Rahman
}

Department of Animal Production, Faculty of Agriculture,-Fayoum University

\section{SUMMARY}

Thirteen primiparous Egyptian buffaloes (Babalus bubalis) were chosen at their late pregnancy (2 months before calving) and were closely monitored throughout the days near the expected date of calving. They calved during the period from November until December 2013. The buffalo heifers were divided into three groups according to their lactation period (LP). The first group (G1) was those lactated more than (7) months and the second group (G2) were those lactated less than (7) months. Whereas, the third group (G3) were those did not lactate postcalving. Milk samples $(30 \mathrm{ml}$ each) were collected once weekly from each lactating buffalo. Milk samples were collected simultaneously at the same day of collecting blood samples at 6:00 am and 6:00 pm. Milk samples were kept frozen at $\left(-20^{\circ} \mathrm{C}\right)$ in the present study. The average lactation period (LP) in G1 (225 day) was higher than that in G2 (175 day). Milk total solids decreased from $17.71 \%$ (in early lactation) to $16.69 \%$ (in mid lactation). Also, in G2 it decreased from $16.93 \%$ (in early lactation) to $15.11 \%$ (in mid lactation). Values of milk solids not fat (SNF \%) were insignificantly higher in G2 than that in G1. The percentage of SNF in early lactation was higher than that in mid and late lactation. The milk fat \% was significantly $(P \leq 0.01)$ higher in $G 1$ than that in $G 2$ by $34.22 \%$ during the lactation period. Also, There was significant $(p \leq 0.01)$ increase in milk fat \% from early to late lactation in G1 compared to G2. Milk protein \% was higher in G1 than that in G2 by $6.96 \%$. Milk lactose percentage was significantly ( $p \leq 0.01)$ higher in G2 than in $G 1$ by $18.1 \%$. Milk water was significantly $(P \leq 0.01)$ higher in $G 2$ than that in $G 1$. The blood plasma Insulin like growth factor-1 (IGF-1 $\mathrm{ng} / \mathrm{ml})$ was significantly and gradually increased starting at precalving to postcalving periods. During the precalving period, G1 showed a significant decrease in PRL concentration from $200.67 \pm 3.18 \mathrm{ng} / \mathrm{ml}$ at day -30 to $198.16 \pm 4.07 \mathrm{ng} / \mathrm{ml}$. at the day of calving. The concentrations of IGF-1 through the lactation stages (early, mid and late lactation) were significantly steadly increased with the advancement of lactation in both groups. The prolactin PRL concentration in G1 was slightly higher in early and mid lactation than that in late lactation. In conclusion the level of blood plasma IGF-1 and PRL during the last 2 month of gestation give a good indicator to the lactation period and milk yield production.

Keywords: Egyptian buffaloes, insulin like growth factor- 1(IGF-1), prolactin (PRL), lactation

\section{INTRODUCTION}

The Buffalo population in Egypt represents $47 \%$ of the total population of Bovine (Galal and Elbeltagy, 2007). According to FAOSTAT (2013), the buffalo population in Egypt has increased from $3,250,000$ heads in 1993 to about 4,200,000 heads in 2013 and decreased to $3,950,000$ heads in 2014. This increasing trend might be due to the high demand for buffalo products such as milk, cheese and butter.

Recently, more attention has been focused on dairy buffaloes because there are many problems, severely, affecting their reproduction and lactation. One of this problems that buffalo heifers stopped lactating after first calving or lactating for a short time and do not complete the lactation season. Previous studies found that the percentage of heifers that stopped lactating after first calving in government farms was more than $40 \%$ and so this is a national problem of wastage of national wealth of Animal Production in Egypt.

The endocrine system plays a central role in all aspects of mammary gland development (Akers, 2006). During the latter time, estogene either remains high or continues to increase and PRL is elevated markedly in blood plasma and mammary blood flow rates increase. The extent of transfer and accumulation of hormones during prepartum in alveolar- lumina may have an important effect on the onset of lactation (Keller et al., 1977). IGF-I can also induce some degree of mammary development in the form of TEB development, indicating other mechanisms of IGF-I action are likely in addition to inhibition of apoptosis (Kleinberg, 1998). Third, expression of IGF-I in mammary tissue can be elevated by exogenous GH and E2. Last, localized administration of IGF-I to the mammary gland of E2treated hypophysectomized- ovariectomized ratscan stimulate ductal development (Ruan et al., 1992).

The present work was executed to evaluate the milking capacity of Egyptian buffalo heifers in their first calving in relation to blood hormones specially PRL and IGF-1, during the last month of pregnancy (precalving period), at calving day and during the lactation period.

\section{MATERIALS AND METHODS}

This study was carried out at the Experimental station of Animal Production, Faculty of Agriculture, Fayoum University, Fayoum, Egypt. The study lasted 
for 12 months from the beginning of September, 2013 until the end of Augustm 2014 to cover both calving and lactation periods.

\section{Experimental design:}

Thirteen primiparous Egyptian buffaloes (Babalusbubalis) were chosen at their late pregnancy ( 2 months before expected calving) and were closely monitored throughout the days near the expected day of calving. They calved during the period from November until December, 2013.

Buffaloes were housed in semi-shaded open yards and they were maintained under the same managerial and environmental conditions. They were fed according to N.R.C (2001). The nutrient requirements were adjusted according to the buffalo's live body weight (BW), pregnancy status, and subsequent milk production of each buffalo.
After calving, buffaloes were hand milked twice a day at 6:00 am and 6:00 pm. The experimental work lasted until the experimental buffaloes stop their lactation. Lactation period was divided into three stages early, mid and late according to Metry and Mourad (1994).

The available thirteen buffalo heifers were divided into three groups according to their lactation period (LP). The first group (G1) was those lactated more than (7) months and the second group (G2) were those lactated less than (7) months. Whereas, the third group (G3) were those that did not lactate postcalving. The present work is executed to evaluate the milking capacity of the experimental Egyptian buffalo heifers in first calving in relation to the examined blood hormones (PRL and IGF-1).

Table 1. Age (month) and body weight $(\mathrm{kg})$ of the experimental buffaloes at calving

\begin{tabular}{cccc}
\hline \multirow{2}{*}{ Animal No } & Group & \multicolumn{2}{c}{ Buffalo cows } \\
\cline { 3 - 4 } & & Age (month) & Weight (kg) \\
\hline 1 & & 28 & 410 \\
3 & $\mathrm{G} 1$ & 34 & 420 \\
4 & & 27 & 350 \\
5 & & 26 & 320 \\
Average & & 35 & 350 \\
6 & & 30 & 370 \\
\hline 7 & $\mathrm{G} 2$ & 38 & 430 \\
8 & & 34 & 300 \\
9 & & 27 & 300 \\
10 & 34 & 360 \\
Average & 26 & 370 \\
11 & & 31.8 & 352 \\
12 & & 34 & 330 \\
Average & & 27 & 320 \\
\hline
\end{tabular}

Experimental procedures:

Milk sampling and analysis:

Milk samples (30 ml each) were collected by hand milking once weekly from each lactating buffalo and milk samples were collected simultaneously at the same day of collecting blood samples at 6:00 am and 6:00 pm. Milk samples were kept frozen at $\left(-20^{\circ} \mathrm{C}\right)$ until the chemical analysis was executed. Percentages of milk fat (F \%), milk lactose (L\%), milk protein (P \%), milk total solids (TS \%), milk density, water content $\%$, milk solids not fat (SNF \%) and milk freezing point (FP) were determined by Ekomilk ${ }^{\circledR}$ analyzer (KAM 98-2A USA) at the time of collecting the samples. Daily milk yield (DMY, Kg), total milk yield (TMY, Kg) and lactation period (LP/day) were recorded for each buffalo alongside.

\section{Blood sampling and analysis:}

Blood samples were collected two months before the expected day of calving $(10 \mathrm{ml}$ each $)$ were collected. The samples were collected from the Jugular vein in heparinized tubes of the thirteen fasted buffaloes using $10 \mathrm{~cm}$ syringes, The sample tube was centrifuged at $3500 \mathrm{rpm}$ for 20 minutes to separate clear blood plasma, which was stored at ($20^{\circ} \mathrm{C}$ ) until hormones assessments

During the first month before calving, the samples were collected biweekly, whereas during the second month the samples were collected weekly. At the time, near to the expected day of calving the samples were collected three times per week: 7, 5, and 2 days prepartum and a sample was obtained on the day of calving ( 0 day). A similar procedure was carried out three times during the first week postcalving at 2, 5 and 7 days. Consequent samples were collected monthly until the beginning of their dry period.

\section{Assessment of relevant blood hormones:}

Special commercial kits were used to quantify blood plasma according to the procedures outlined by the manufactures. These hormones were prolactin (PRL) and insulin - like growth factor- 1 (IGF-1). These two hormones were determined in all buffalo groups (G1, G2 and G3) during pericalving period. Whereas during lactation period (PRL and IGF-1) were determined in the lactating groups only (G1 and 
G2). Averages of these hormones in G1 and G2 were calculated and considered as the averages of the lactating buffalo (LB) versus the averages in G3 as a non-lactating buffalo (NLB). Hormone averages of all buffalo heifers (G1, G2 and G3) during the precalving at calving day and postcalving periods were calculated and considered as the overall means for these periods.

\section{Prolactin $(n g / m l):$}

Immunoradiometric assay (IRMA) technique was used to quantify blood plasma prolactin (PRL) by SHIN MEDICSINC. (RIAKEY PROLACTIN IRMA TUBE USA). The concentration of PRL are expressed as nanorgam per milliliter ( $\mathrm{ng} / \mathrm{ml})$. The antibodies highly specific for PRL with extremely low cross reactivity against several related molecules. The analytical sensitivity was $0.65 \mathrm{ng} / \mathrm{ml}$. The coefficients of variation in intra-assay were found below or equal to $2.8 \%$ and $8 \%$ respectively.

\section{Insulin- like growth factor- 1 (IGF-1) (ng/ml):}

Immunoradiometric assay (IRMA) technique was used to quantify blood plasma Insulin- like growth factor 1 by SHIN MEDICSINC. (RIAKEY PROLACTIN IRMA TUBE USA). The concentrations of IGF-1 are expressed as nanorgam per milliliter (ng/ml). The analytical sensitivity was 2 $\mathrm{ng} / \mathrm{ml}$. the antibodies used in the immunoassay are highly specific for IGF-1 with low cross reactivities against several molecules.

\section{Statistical analysis:}

A general linear model procedure according to SPSS 21 (2012) was used for the statistical analysis of hormonal profile during the precalving period using the following model:

$$
\mathrm{Y}_{\mathrm{ijk}}=\mu+\mathrm{P}_{\mathrm{i}}+\mathrm{A}(\mathrm{P})_{\mathrm{ik}}+\mathrm{G}_{\mathrm{j}}+(\mathrm{P} * \mathrm{G})_{\mathrm{ij}}+\mathrm{e}_{\mathrm{ijk}}
$$

Where,

$\mathrm{Y}_{\mathrm{ijk}}=$ Any observation of $\mathrm{k}^{\text {th }}$ animals within $\mathrm{j}^{\text {th }}$ group within $i^{\text {th }}$ period.

$$
\begin{aligned}
& \mu=\text { Overall mean } \\
& \mathrm{P}_{\mathrm{i}}=\text { Effect of } \mathrm{i}^{\text {th }} \text { period }(\mathrm{I}=-30,-15,-7,-5,-2,0,2,5,7)
\end{aligned}
$$

$\mathrm{A}(\mathrm{P})_{\mathrm{ik}}=$ the repeated of $\mathrm{k}^{\text {th }}$ animals within $\mathrm{i}^{\text {th }}$ period. $\mathrm{G}_{\mathrm{j}}=$ Effect of $\mathrm{j}^{\text {th }}$ group $(\mathrm{j}=1-3,1=\mathrm{G} 1,2=\mathrm{G} 2,3=\mathrm{G} 3$ ) $\left(\mathrm{P}^{*} \mathrm{G}\right)_{\mathrm{ij}}=$ the interaction between periods and groups.

$\mathrm{e}_{\mathrm{ijk}}=$ Experimental error assumed to be randomly distributed from 0 to $\partial 2$

Another general linear model procedure according to SPSS 21 (2012) was used for the statistical analysis of the milk yield and milk composition, during the experimental period using the following model:

$\mathrm{Y}_{\mathrm{ijk}}=\mu+\mathrm{P}_{\mathrm{i}}+\mathrm{A}(\mathrm{P})_{\mathrm{ik}}+\mathrm{G}_{\mathrm{j}}+(\mathrm{P} * \mathrm{G})_{\mathrm{ij}}+\mathrm{e}_{\mathrm{ijk}}$

Where,

$\mathrm{Y}_{\mathrm{ijk}}=$ Any observation of $\mathrm{k}^{\text {th }}$ animals within $\mathrm{j}^{\text {th }}$ group within $\mathrm{i}^{\text {th }}$ experimental period.

$\mu \quad=$ Overall mean

$\mathrm{P}_{\mathrm{i}} \quad=$ Effect of $\mathrm{i}^{\text {th }}$ period $(\mathrm{I}=$ lactation months $)$.

$\mathrm{A}(\mathrm{P})_{\mathrm{ik}}=$ the repeated of $\mathrm{k}^{\text {th }}$ animals within $\mathrm{i}^{\text {th }}$ experimental period.

$\mathrm{G}_{\mathrm{j}}=$ Effect of $\mathrm{j}^{\text {th }}$ group $(\mathrm{j}=1-2,1=\mathrm{G} 1,2=\mathrm{G} 2)$

$(\mathrm{P} * \mathrm{G})_{\mathrm{ij}}=$ the interaction between experimental periods and groups.

$\mathrm{e}_{\mathrm{ijk}}=$ Experimental error assumed to be randomly distributed from 0 to $\partial 2$

\section{RESULTS AND DISCUSSION \\ Lactation performance: \\ Milk yield $(\mathrm{kg} / \mathrm{d})$ :}

As shown in Table (2) the average lactation period (LP) in G1 was higher than that in G2. The average daily milk yield (DMY) of both groups during different lactation stages are presented in Table (3). Total milk yield (TMY) in the two groups ( $\mathrm{G} 1$ and G2) is lower than that recorded by Pawar et al. (2013) who found that the TMY in Egyptian buffaloes is $1576 \mathrm{~kg}$. In addition, the average of DMY of lactating Egyptian buffalo in the present study is higher in G1 than that recorded by Abouzeina et al. (2009). They found that the averages DMY in buffaloes were $3.97 \mathrm{~kg}$ but lower than that recorded by Farouk (2012) reported that the average DMY in buffaloes was $4.5 \mathrm{~kg}$.

\begin{tabular}{|c|c|c|c|c|}
\hline \multirow{2}{*}{ Group } & \multirow{2}{*}{$\begin{array}{l}\text { Animal } \\
\text { No. }\end{array}$} & \multirow{2}{*}{$\begin{array}{l}\text { Lactation period/ } \\
\text { (day) }\end{array}$} & \multirow{2}{*}{$\begin{array}{l}\text { Total milk yield/ } \\
\text { (K.g) }\end{array}$} & \multirow{2}{*}{$\frac{\text { Daily milk yield (K.g) }}{\text { Mean } \pm \text { S.E }}$} \\
\hline & & & & \\
\hline \multirow{5}{*}{ G1 } & 1 & 203 & 1101.86 & $4.71 \pm 0.79$ \\
\hline & 2 & 224 & 996.43 & $3.81 \pm 0.54$ \\
\hline & 3 & 224 & 1344.47 & $5.37 \pm 0.41$ \\
\hline & 4 & 231 & 998.22 & $3.94 \pm 0.26$ \\
\hline & 5 & 245 & 816.69 & $3.01 \pm 0.46$ \\
\hline \multicolumn{2}{|c|}{ Average } & 225.4 & 1051.53 & 4.17 \\
\hline \multirow{5}{*}{ G2 } & 6 & 161 & 657.16 & $2.88 \pm 0.72$ \\
\hline & 7 & 168 & 755.46 & $3.24 \pm 0.82$ \\
\hline & 8 & 168 & 819.98 & $3.58 \pm 0.90$ \\
\hline & 9 & 189 & 863.03 & $3.72 \pm 0.57$ \\
\hline & 10 & 189 & 769.33 & $3.37 \pm 0.74$ \\
\hline \multicolumn{2}{|c|}{ Average } & 175 & 772.99 & 3.36 \\
\hline
\end{tabular}

Table 2. Lactation period (LP), total milk yield (TMY) and daily milk yield (DMY) of Egyptian buffaloes in the two groups under study (Mean \pm S.E).

G1 $=$ Group that milked more than7 months and G2= Group that milked less than 7 months. 
Table 3.Daily milk yield (DMY, kg) during the three different stages of lactation in Egyptian buffaloes $($ Mean \pm S.E)

\begin{tabular}{|c|c|c|c|}
\hline \multirow{2}{*}{ Group } & \multicolumn{3}{|c|}{ Stage of lactation } \\
\hline & Early & Mid & Late \\
\hline G1 & $3.78 \pm 0.44$ & $4.93 \pm 0.41$ & $3.79 \pm 0.57$ \\
\hline G2 & $2.94 \pm 0.32$ & $4.73 \pm 0.16$ & $2.4 \pm 0.24$ \\
\hline
\end{tabular}

G1 = Group that milked more than 7 months and G2= Group that milked less than 7 months.

\section{Milk composition:}

Results of milk total solids (TS \%) for the lactating Egyptian buffaloes are shown in Tables (4 and 5). Table (4) showed that T.S is higher $(\mathrm{P} \leq 0.01)$ in G1 than that G2. Table 5 shows that in G1 the percentage of TS decreased from $17.71 \%$ (in early lactation) to $16.69 \%$ (in mid lactation). Also, in G2 it decreased from $16.93 \%$ (in early lactation) to $15.11 \%$ (in mid lactation). Generaly, the decrease in TS level was higher in G2 $(10.75 \%)$ than G1 $(5.76 \%)$. The decrease in TS percentage during the early stage of lactation may be due to the increase in the milk production in the peak of lactation during this period, and the more dilution of milk by transportation of water. These data are similar to those reported by Gurmessa and Melaku (2012) who found that the percentage of TS in lactating buffaloes was $13.37 \%$ and $12.13 \%$ in early and mid lactation, respectively. Values of milk solids not fat (SNF \%) presented in Tables (4 and 5) and Figs. (2 - 3) were slightly increased in $\mathrm{G} 2$ than that in G1 but insignificantly (9.93\% in G2 vs. 9.52 in G1). The percentage of SNF in early lactation was higher than that in mid and late lactation, $10.83,9.62$ and 8.86 vs. $11.56,9.81$ and 8.29 , respectively. But between the stages of lactation it was significantly $(\mathrm{P} \leq 0.01)$ in early lactation than mid and late lactation period. These data are in agreement with those reported by Mahdi (2014) who reported that SNF content was unchanged significantly $(\mathrm{P} \leq 0.05)$ by the lactation period.

Percentage of milk fat (F \%) in the two lactation groups of Egyptian buffalo are presented in Table (4 and 5). Generally, it was noticed that $\mathrm{F} \%$ was higher $(\mathrm{P} \leq 0.01)$ in $\mathrm{G} 1$ than that in $\mathrm{G} 2$ by $34.22 \%$ during the lactation period. As shown in Table (5) there was a higher significant $(\mathrm{P} \leq 0.01)$ increase in $\mathrm{F} \%$ from early to late lactation in G1 compared to G2. This could be attributed to the inverse relationship between the fat percentage and the amount of milk yield. The present data for G1 was higher than that recorded by Seema and Quazi (2014). They found that the percentage of $\mathrm{F} \%$ in lactating buffaloes was $6.38 \%$. However, these previous studies are in close agreement with the results of $\mathrm{G} 2$.

Milk protein percentages of lactating Egyptian buffaloes are illustrated in Tables (4 and 5). In general, milk protein \% was higher in G1 than that in $\mathrm{G} 2$, but this increase was insignificant. But, between the stages of lactation there was a significant $(\mathrm{P} \leq$ 0.01 ) difference in early lactation than mid and late lactation period in G1 and G2. These results are due to positive and high correlations between total lipids and total protein in buffalo milk therefore they increased in the same direction. Milk protein (\%) in
G1 (4.3\%) was higher than those recorded by Seema and Quazi (2014). They found that the percentages of protein in lactation buffaloes were 4.03. However, these previous studies are in close agreement with the recorded data of G2 $(4.02 \%)$.

In general, milk lactose percentage (L) was significantly $(\mathrm{P} \leq 0.05)$ higher in $\mathrm{G} 2$ than in $\mathrm{G} 1$ by $18.1 \%$ (Table 4 ). The results show that there was a high significant $(\mathrm{P} \leq 0.01)$ decrease from early to late lactation period in G2. Concerning the lactation stage, L \% percentages in G1 was highly $(\mathrm{P} \leq 0.01)$ lower in early lactation stage than that in mid lactation, where it increased from $4.48 \%$ to $5.36 \%$. Also, the present results are in agreement with Mahdi (2014) who reported that the maximum concentration of lactose is observed during early lactation was 4.53 $\mathrm{g} / \mathrm{L}$ and decrease significantly to $3.38 \mathrm{~g} / \mathrm{L}$ in late lactation. The present data are higher than those reported by Seema and Quazi (2014). They found that the percentages of $\mathrm{L} \%$ in lactating buffaloes were 4.19 and $4.21 \%$, respectively.

Percentages of milk ash in the two lactation groups (G1 and G2) of Egyptian buffalo are presented in Tables (4 and 5). Generally, it was noticed that milk ash was insignificantly increase in G1 than G2. Concerning the lactation stage, milk ash percentages was increased $(\mathrm{P} \leq 0.01)$ in late lactation stage than that in early and mid lactation, where it increased from $0.79 \%$ to $0.83 \%$ in late lactation in G1. The decrease in milk ash percentage during mid lactation may be due to the increase milk production within the peak of lactation and the more dilution of milk by transportation of water into milk. The increase of milk ash percentage in late lactation may be due to the decrease of both milk yield and water secretion during these periods, which support the present result. The present result are in agreement with Mahdi (2014) who reported that milk ash of buffalo milk increased $(\mathrm{P} \leq 0.05)$ by the end of lactation stage compared with the beginning of lactation stage, the values were $(0.84$ and 0.71$) \mathrm{g} / \mathrm{L}$ respectively. The present data are higher than those reported by Seema and Quazi (2014), who found that the percentages of milk ash in lactating buffaloes was $0.64 \%, 0.72 \%$ and $0.72 \%$, respectively.

Percentage of milk water in the two lactation groups of Egyptian buffalo G1 and G2 are shown in Tables (4 and 5). Generally, it was noticed that milk water was higher $(\mathrm{P} \leq 0.05)$. in $\mathrm{G} 2$ than that in $\mathrm{G} 1$. Concerning the lactation stage, milk water percentages were lower $(\mathrm{P} \leq 0.01)$ in $\mathrm{G} 1$ in early lactation stage than that in mid and late lactation, and the same result was found in $\mathrm{G} 2$. These results may be due to the increase in T.S \% and S.N. F\%, in early 
lactation to late lactation. The present data are higher than those reported by Mahdi (2014) who reported that the milk water percentage in early, mid and late lactation was $(81.93 \%, 82.01 \%)$ and $82.41 \%$ respectively.

Milk density values in the two lactation groups of Egyptian buffalo are shown in Table (4 and 5). Generally, it was noticed that milk density was insignificantly higher in G2 than that in G1 by $1.5 \%$. Concerning the lactation stage, milk water percentages in $\mathrm{G} 1$ was higher $(\mathrm{P} \leq 0.01)$ significantly in early lactation stage than that in mid and late lactation, the same result was found in G2.The present data of milk density are higher than those reported by Mahdi (2014), who reported that density was significantly $(\mathrm{P} \leq 0.05)$ decreased by the progress of lactation period.

Milk freezing point values in the two lactation groups of Egyptian buffalo G1 and G2 are shown in Tables (4 and 5). Generally, it was noticed that milk freezing point was insignificantly higher in G2 than in G1.Concerning the lactation stage, milk freezing point in G1 was insignificantly decrease in early lactation stage than that in mid and late lactation. The present data are close to those reported by Mahdi (2014), who reported that the freezing point was decreased significantly $(\mathrm{P} \leq 0.05)$ in early lactation compared to late lactation.

Table 4. Milk components and some characteristics percentages (mean \pm S.E) during lactation period in Egyptian buffaloes.

\begin{tabular}{lcc}
\hline \multirow{2}{*}{ Milk components } & \multicolumn{2}{c}{ Lactating groups } \\
\cline { 2 - 3 } Total solids T.S \% & $\mathrm{G} 1$ & $\mathrm{G} 2$ \\
S.N.F \% & $16.82^{\mathrm{A}} \pm 0.14$ & $15.22^{\mathrm{B}} \pm 0.26$ \\
Fat \% & $9.52 \pm 0.15$ & $9.93 \pm 0.22$ \\
Protein \% & $7.1^{\mathrm{A}} \pm 0.06$ & $5.29^{\mathrm{B}} \pm 0.05$ \\
Lactose \% & $4.3 \pm 0.11$ & $4.02 \pm 0.08$ \\
Ash \% & $4.42^{\mathrm{b}} \pm 0.18$ & $5.22^{\mathrm{a}} \pm 0.25$ \\
Water \% & $0.79 \pm 0.01$ & $0.78 \pm 0.01$ \\
Density (ml/gm) & $83.38^{\mathrm{B}} \pm 0.14$ & $84.78^{\mathrm{A}} \pm 0.26$ \\
Freezing point $\left(\mathbf{(}^{\mathbf{c}} \mathbf{c}\right)$ & $52.81 \pm 0.56$ & $53.61 \pm 0.93$ \\
\hline
\end{tabular}

G1 = Group that milked more than 7 months and G2= Group that milked less than 7 months.

Means having different superscriptswithin the same row are different $(\mathrm{P} \leq 0.01)$ or $(\mathrm{P} \leq 0.05)$.

Table 5. Milk components and some characteristics percentage (Mean \pm S.E) during the three different stages of lactation in Egyptian buffaloes

\begin{tabular}{|c|c|c|c|c|c|c|}
\hline \multirow{3}{*}{$\begin{array}{c}\text { Milk } \\
\text { components }\end{array}$} & \multicolumn{6}{|c|}{ Stage of lactation } \\
\hline & \multicolumn{2}{|c|}{ Early } & \multicolumn{2}{|c|}{ Mid } & \multicolumn{2}{|c|}{ Late } \\
\hline & G1 & G2 & G1 & G2 & G1 & G2 \\
\hline Total solids T.S & $17.71^{\mathrm{A}} \pm 0.24$ & $16.93^{\mathrm{AB}} \pm 0.20$ & $16.69^{\mathrm{AB}} \pm 0.20$ & $15.11^{C_{ \pm}} \pm 0.31$ & $16.08^{\mathrm{BC}} \pm 0.21$ & $13.42^{C} \pm 0.19$ \\
\hline S.N.F & $10.83^{\mathrm{A}} \pm 0.18$ & $11.56^{\mathrm{A}} \pm 0.12$ & $9.62^{\mathrm{B}} \pm 0.23$ & $9.81^{\mathrm{B}} \pm 0.27$ & $8.86^{\mathrm{BC}} \pm 0.17$ & $8.29^{\mathrm{C}} \pm 0.25$ \\
\hline Fat & $6.88^{\mathrm{A}} \pm 0.12$ & $5.37^{\mathrm{B}} \pm 0.09$ & $7.07^{\mathrm{A}} \pm 0.08$ & $5.29^{\mathrm{B}} \pm 0.06$ & $7.22^{\mathrm{A}} \pm 0.09$ & $5.14^{\mathrm{B}} \pm 0.13$ \\
\hline Protein & $5.61^{\mathrm{A}} \pm 0.16$ & $4.35^{\mathrm{C}} \pm 0.04$ & $3.47^{\mathrm{D}} \pm 0.06$ & $3.85^{\mathrm{D}} \pm 0.10$ & $5.06^{\mathrm{B}} \pm 0.09$ & $4.55^{C} \pm 0.07$ \\
\hline Lactose & $4.48^{\mathrm{B}} \pm 0.19$ & $6.51^{\mathrm{A}} \pm 0.12$ & $5.36^{\mathrm{B}} \pm 0.23$ & $5.3^{\mathrm{B}} \pm 0.30$ & $2.96^{\mathrm{C}} \pm 0.20$ & $2.88^{\mathrm{C}} \pm 0.23$ \\
\hline Ash & $0.74^{\mathrm{C}} \pm 0.01$ & $0.7^{\mathrm{D}} \pm 0.004$ & $0.79^{\mathrm{B}} \pm 0.01$ & $0.79^{\mathrm{B}} \pm 0.01$ & $0.83^{\mathrm{A}} \pm 0.004$ & $0.85^{\mathrm{A}} \pm 0.01$ \\
\hline Water & $82.29^{\mathrm{D}} \pm 0.24$ & $83.07^{\mathrm{CD}} \pm 0.20$ & $83.31^{\mathrm{CB}} \pm 0.20$ & $84.89^{\mathrm{B}} \pm 0.31$ & $83.92^{\mathrm{BC}} \pm 0.21$ & $86.58^{\mathrm{A}} \pm 0.19$ \\
\hline Density (ml/gm) & $55.93^{\mathrm{A}} \pm 0.33$ & $55.08^{\mathrm{A}} \pm 0.58$ & $54.81^{\mathrm{A}} \pm 0.49$ & $54.36^{\mathrm{A}} \pm 0.43$ & $48.54^{\mathrm{B}} \pm 1.02$ & $47.21^{\mathrm{B}} \pm 1.98$ \\
\hline Freezing point $\left({ }^{\circ} \mathrm{c}\right)$ & $28.12 \pm 2.76$ & $28.56 \pm 2.76$ & $29.8 \pm 0.72$ & $30.95 \pm 0.35$ & $28.49 \pm 1.92$ & $28.21 \pm 4.24$ \\
\hline
\end{tabular}

G1 $=$ Group that milked more than 7 months and G2= Group that milked less than 7 months.

Means having different superscripts within the same row are different $(\mathrm{P} \leq 0.01)$.

\section{Blood plasma hormones: \\ Precalving period:}

Insulin like growth factor $1 \mathrm{IGF}-1$ ( $\mathrm{ng} / \mathrm{ml})$ :

Generally, IGF-1 (ng/ml) was increased $(\mathrm{P} \leq 0.01)$ gradually starting at precalving to postcalving periods (Table 6). In G1, IGF-1 concentration was low at -15 day before calving $(82.93 \mathrm{ng} / \mathrm{ml})$ then start to increase in -7 and -5 day before calving ( 88.21 and $106.91 \mathrm{ng} / \mathrm{ml}$ respectively) then slightly decreased at -2 days $(105.21 \mathrm{ng} / \mathrm{ml})$ and then increased again at the day of calving reaching $(120.24 \mathrm{ng} / \mathrm{ml})$.

During the postcalving period the concentration of IGF-1 fluctuated, it decreased at 2 days (80.36 $\mathrm{ng} / \mathrm{ml}$ ) postcalving then increased to reach the peak at
5 days and then it decreased again at $7^{\text {th }}$ day. However, it was still higher than its concentration at $2^{\text {nd }}$ day postcalving. This means that the concentration of IGF-1 was elevated during the postcalving period.

In $\mathrm{G} 2$ as in G1, concentration of IGF-1 was lower at $-30,-15$ and -7 days precalving than days -5 and increased in day -2 precalving. However, a higher $(\mathrm{P} \leq 0.01)$ decrease was observed at the day of calving. This reduction continued until the $2^{\text {nd }}$ day post calving. At day +5 the level of IGF-1was high $(\mathrm{P} \leq 0.01)$ and increased to reach the peak then decreased again at day $7^{\text {th }}$ post calving, however, it was still higher than its concentration at $2^{\text {nd }}$ day post 
calving. It was noticeable that the concentration of IGF-1 at day $7^{\text {th }}$ was higher in G2 than G1 by $34.1 \%$ (Table, 6).

In $\mathrm{G} 3$, no considerable change in IGF-1 concentration was observed during precalving period. However, at day of calving there was a slight increase in its level. This increase continued until day 2 postcalving then declined at day 5 post calving (the opposite was observed in G1 and G2) and increased again at the $7^{\text {th }}$ day of calving.

The present results are in agreement with those of Miliet al. (2015) who reported that IGF-I registered a massive decline around calving day of buffaloes as compared to prepartum period. Level of IGF-I in supplemented group declined from $177.90 \pm$ $33.51 \mathrm{ng} / \mathrm{ml}$ on day 21 before calving to $140.35 \pm$ 5.49 on the day of calving. The level continued to decline in postpartum period, eventually reaching to $117.53 \pm 6.24 \mathrm{ng} / \mathrm{ml}$ on day 21 postpartum. The concentration enhanced from $144.66 \pm 19.41$ on day 21 to $1.80 .58 \pm 21.76 \mathrm{ng} / \mathrm{ml}$ on day -7 prepartum followed by a significant decline to $123.80 \pm 4.53$ on day of parturition.

In lactating buffalo, IGF-1 increased gradually from pre to postcalving period contrast to non lactating buffalo which was decreased in postcalving period. It also noticed that, its concentration was higher in LB than that in NLB by $17.96 \%, 19.94 \%$ and $51.19 \%$ in precalving and postcalving period respectively as showen in Table (8). Data presented in Table (9) indicated that IGF-1 was significantly increased in pre calving than post calving.

\section{Prolactin PRL:}

Data of the concentrations of prolactin (PRL, $\mathrm{ng} / \mathrm{ml}$ ) during precalving stage illustrated in Table (7). During the precalving period, G1 showed a significant $(\mathrm{P} \leq 0.01)$ decrease in $\mathrm{PRL}$ concentration from $200.67 \pm 3.18 \mathrm{ng} / \mathrm{ml}$ at day -30 to $198.16 \pm 4.07$ $\mathrm{ng} / \mathrm{ml}$. at the day of calving. But during the postpartum period, PRL concentration was considerably higher in G1 than that in G2 at the same time.

The concentration of PRL in G3 was high $(\mathrm{P} \leq$ 0.01 ) and increased during precalving period and generaly remained increasing till calving day and postcalving.

Data presented in Table (9) indicated that PRL concentration during postcalving is higher than that in precalving period.

Results are different from those reported by Surendra and Ram (2012) they reported that prolactin concentration was higher at the day of parturition. Thus, due to itsgalactopoietic activity, A. racemases can be considered as an alternative of lactogenic hormones for enhancing the milk yield (Kumar et al., 2011).

Table 6. Plasma IGF-1 (ng/ml) in Egyptian buffaloes from one month precalving to 7 days postcalving $($ Mean \pm S.E)

\begin{tabular}{|c|c|c|c|c|c|c|c|c|c|c|}
\hline \multirow[t]{2}{*}{ Group } & \multicolumn{5}{|c|}{ Precalving/day } & \multirow{2}{*}{$\begin{array}{c}\begin{array}{c}\text { Calving } \\
\text { day }\end{array} \\
\mathbf{0}\end{array}$} & \multicolumn{3}{|c|}{ Postcalving/day } & \multirow{2}{*}{ Average } \\
\hline & -30 & -15 & -7 & -5 & -2 & & +2 & +5 & +7 & \\
\hline \multirow{2}{*}{ G1 } & $83.65 \pm$ & $82.93 \pm$ & $88.21 \pm$ & $106.91 \pm$ & 105.21 & 120.24 & 80.36 & 125.24 & 98.57 & $99.04^{\mathrm{A}}$ \\
\hline & 4.3 & 4.87 & 4.04 & 5.97 & \pm 6.03 & \pm 5.76 & \pm 2.96 & \pm 4.98 & \pm 3.18 & \pm 3.34 \\
\hline \multirow{2}{*}{ G2 } & $53.47 \pm$ & 55.23 & $55.27 \pm$ & $98.23 \pm$ & $109.08 \pm$ & 75.25 & 71.27 & 156.27 & 149.57 & $91.51^{\mathrm{A}}$ \\
\hline & 4.36 & \pm 3.97 & 3.03 & 1.54 & 2.52 & \pm 2.9 & \pm 3.79 & \pm 3.09 & \pm 2.3 & \pm 7.41 \\
\hline Average & 68.56 & 69.08 & 71.74 & 102.57 & 107.15 & 97.74 & 75.82 & 140.76 & 124.07 & 95.28 \\
\hline \multirow{2}{*}{ G3 } & $68.62 \pm$ & 70.49 & $70.8 \pm$ & $71.27 \pm$ & $74.13 \pm$ & 81.47 & 79.21 & 71.87 & 74.23 & $73.57^{\mathrm{B}}$ \\
\hline & 4.39 & \pm 4.17 & 3.92 & 4.04 & 4.47 & \pm 5.71 & \pm 3.96 & \pm 1.67 & \pm 0.61 & \pm 1.3 \\
\hline $\begin{array}{l}\text { Overall } \\
\text { mean }\end{array}$ & $\begin{array}{l}68.58 \\
D\end{array}$ & $\begin{array}{l}69.55 \\
D\end{array}$ & $71.43^{\mathrm{D}}$ & $92.14^{\mathrm{BCD}}$ & $96.14^{\mathrm{BC}}$ & $92.32^{\mathrm{BCD}}$ & $76.94^{\mathrm{D}}$ & $117.79^{\mathrm{A}}$ & $107.46^{\mathrm{AB}}$ & 88.04 \\
\hline
\end{tabular}

G1 = Group that milked more than 7 months, G2= Group that milked less than 7 months and G3= Group that did not lactate. Means having different supersciptswithin the same column are different $(\mathrm{P} \leq 0.01)$.

Table 7. Plasma prolactin PRL (ng/ml) in Egyptian buffaloes from one month precalving to 7 days postcalving (Mean \pm S.E)

\begin{tabular}{|c|c|c|c|c|c|c|c|c|c|c|}
\hline \multirow[t]{2}{*}{ Group } & \multicolumn{5}{|c|}{ Precalving/ day } & \multirow[t]{2}{*}{$\begin{array}{l}\text { Calving } \\
\text { day }\end{array}$} & \multicolumn{3}{|c|}{ Postcalving/ day } & \multirow[t]{2}{*}{ Average } \\
\hline & -30 & -15 & -7 & -5 & -2 & & +2 & +5 & +7 & \\
\hline \multirow{2}{*}{ G1 } & $200.67 \pm$ & 200 & 225 & 188 & 196.63 & 198.16 & 199.16 & 204.57 & 212.31 & $202.72^{\mathrm{A}}$ \\
\hline & 3.18 & \pm 2.89 & \pm 2.52 & \pm 6.81 & \pm 6.53 & \pm 4.87 & \pm 6.65 & \pm 9.94 & \pm 8.49 & \pm 2.61 \\
\hline \multirow{2}{*}{ G2 } & 236.48 & 236.52 & 236.22 & 170.54 & 177.89 & 183.51 & 184.89 & 193.91 & 190.19 & $201.13^{\mathrm{A}}$ \\
\hline & \pm 1.78 & \pm 1.81 & \pm 2.01 & \pm 4.33 & \pm 2.89 & \pm 3.29 & \pm 3.47 & \pm 1.99 & \pm 1.12 & \pm 5.1 \\
\hline Average & 218.57 & 218.26 & 230.61 & 179.27 & 187.26 & 190.83 & 192.02 & 199.24 & 201.25 & 201.93 \\
\hline \multirow{2}{*}{ G3 } & 91.14 & 93.77 & 94.54 & 170.18 & 180.48 & 181.9 & 185.8 & 188.13 & 186.47 & $152.49^{\mathrm{B}}$ \\
\hline & \pm 1.15 & \pm 3.27 & \pm 2.36 & \pm 5.81 & \pm 5.43 & \pm 7.26 & \pm 7.78 & \pm 4.19 & \pm 4.13 & \pm 8.4 \\
\hline $\begin{array}{l}\text { Overall } \\
\text { mean }\end{array}$ & 176.1 & 176.76 & 185.25 & 176.24 & 184.99 & 187.85 & 189.95 & 195.54 & 196.32 & 185.45 \\
\hline
\end{tabular}

G1 = Group that milked more than 7 months, G2= Group that milked less than 7 months and G3= Group that did not lactate. Means having different supersciptswithin the same column are different $(\mathrm{P} \leq 0.01)$. 
Table 8. Blood plasma hormones concentration average during one month precalving to one week postcalving in lactating (LB) and non-lactating (NLB) Egyptian buffaloes(Mean \pm S.E)

\begin{tabular}{lcccc}
\hline Hormones & Groups & precalving & Calving day & Postcalving \\
\hline \multirow{2}{*}{ IGF-1(ng/ml) } & LB & $83.82 \pm 4.06$ & $97.74 \pm 10.47$ & $113.55 \pm 7.99$ \\
& NLB & $71.06 \pm 1.66$ & $81.47 \pm 5.7$ & $75.10 \pm 1.27$ \\
\hline \multirow{2}{*}{ PRL (ng/ml) } & LB & $206.08 \pm 4.53$ & $190.83 \pm 4.20$ & $197.5 \pm 3.07$ \\
& NLB & $126.02 \pm 10.91$ & $181.9 \pm 7.26$ & $186.8 \pm 2.83$ \\
\hline
\end{tabular}

Table 9. Blood plasma hormones concentration average during one month precalving to one week postcalving in Egyptian buffaloes(Mean \pm S.E)

\begin{tabular}{lccc}
\hline Hormone & Precalving & Calving day & Postcalving \\
\hline IGF-1(ng/ml) & $79.57^{\mathrm{b}} \pm 2.89$ & $92.23^{\mathrm{ab}} \pm 7.46$ & $100.73^{\mathrm{a}} \pm 6.37$ \\
\hline PRL (ng/ml) & $179.87 \pm 7.58$ & $187.85 \pm 3.74$ & $193.93 \pm 2.43$ \\
\hline
\end{tabular}

Means having different supersciptswithin the same column are different $(\mathrm{P} \leq 0.01)$.

Lactation period:

Insulin like growth factor -1:

Data in Tables (10 and 11) indicate that the concentrations of Insulin like growth factor-1 (IGF-1 $\mathrm{ng} / \mathrm{ml}$ ) through the lactation stages (early, mid and late lactation) were increased $(\mathrm{P} \leq 0.01)$ steady with the advancement of lactation in both groups there was significant difference $(\mathrm{P} \leq 0.01)$ between the two lactating groups ( $\mathrm{G} 1$ and $\mathrm{G} 2$ ) and it was noticed that the concentration of IGF-1 was higher in G1 than that in $\mathrm{G} 2$ during the three stages of lactation by $40.21 \%$, $22.35 \%$ and $12.86 \%$, respectively. The present data are in agreement with those of Hassan et al. (2014). They found that the concentration of IGF-1 increased as lactation advanced.

Over expression of IGF-1 in the mammary gland led to premature parenchymal development ( $\mathrm{Su}$ and Cheng, 2004) and delayed involution (Hadsell et al., 1996). Second, IGF-I mRNA was detected in mammary tissue from pregnant and lactating cows (Hauser et al., 1990). Mammary tissue from pregnant heifers was separated into fractions of epithelium, stroma, and blood components and IGF-I m RNA was found to be localize in the stromal component of the mammary gland (Cohick, 1998). IGF-I and IGFIR are also expressed within both the epithelial and stromal compartments of the virgin mammary gland (Berry et al., 2001).

\section{Prolactin:}

There was significant difference $(\mathrm{P} \leq 0.01)$ between the two lactating groups G1 and G2 (Table 10). It was noticed that PRL concentration in G1 was slightly higher in early and mid lactation than late lactation. The present results are in agreement with Hassan et al. (2014) who reported that serum prolactin concentration was little changed during the lactating period in lactating buffaloes. The present results are shown in Table (11) and are in agreement with Miller et al. (2006) who reported that there was a significant difference through the lactation stages. They found that PRL concentration is higher in early lactation than that in late lactation in lactating buffaloes.

Table 10. Hormones concentration $(\mathrm{ng} / \mathrm{ml})$ during the three different stages of lactation for Egyptian buffaloes (Mean \pm S.E)

\begin{tabular}{|c|c|c|c|c|c|c|}
\hline \multirow{3}{*}{ Hormone } & \multicolumn{6}{|c|}{ Stage of lactation } \\
\hline & \multicolumn{2}{|c|}{ Early } & \multicolumn{2}{|c|}{ Mid } & \multicolumn{2}{|c|}{ Late } \\
\hline & G1 & G2 & G1 & G2 & G1 & G2 \\
\hline IGF-1 & $150.4^{\mathrm{D}} \pm$ & $107.27^{\mathrm{E}}$ & $183.82^{\mathrm{B}} \pm$ & $150.24^{\mathrm{D}} \pm$ & $194.95^{\mathrm{A}}$ & $172.74^{c}$ \\
\hline (ng/ml) & 2.11 & \pm 1.31 & 1.33 & 1.4 & \pm 0.96 & \pm 2.65 \\
\hline PRL (ng/ml) & $\begin{array}{c}196.87^{\mathrm{A}} \pm \\
4.14\end{array}$ & $\begin{array}{l}185.07^{\mathrm{B}} \pm \\
1.76\end{array}$ & $\begin{array}{l}201.40^{\mathrm{A}} \pm \\
1.25\end{array}$ & $\begin{array}{l}176.57^{\mathrm{C}_{ \pm}} \\
0.67\end{array}$ & $\begin{array}{c}189.24^{\mathrm{B}} \pm \\
1.89\end{array}$ & $\begin{array}{l}171.63^{\circ} \\
\pm 0.48\end{array}$ \\
\hline
\end{tabular}

G1= Groups that milked more than 7 month, G2= Group that milked less than 7 months.

Means having different supersciptswithin the same column are different $(P \leq 0.01)$.

Table 11. Hormones concentration $(\mathrm{ng} / \mathrm{ml})$ during the three different stages of lactation for lactating Egyptian buffaloes (mean \pm S.E)

\begin{tabular}{lccc}
\hline \multirow{2}{*}{ Hormone } & \multicolumn{3}{c}{ Stage of lactation } \\
\cline { 2 - 4 } & Early & Mid & Late \\
\hline IGF-1(ng/ml) & $128.83^{\mathrm{C}} \pm 5.12$ & $167.03^{\mathrm{B}} \pm 3.62$ & $186.06^{\mathrm{A}} \pm 4.58$ \\
PRL (ng/ml) & $190.97 \pm 3.33$ & $188.98 \pm 2.35$ & $182.19 \pm 2.97$ \\
\hline
\end{tabular}

Means having different supersciptswithin the same column are different $(\mathrm{P} \leq 0.01)$.

\section{CONCLUSION}

The noticed trend in the changes in the blood plasma PRL and IGF-1 due to calving date and lactation explain their role in lactogenesis in primiparous buffaloes. Further research is needed to explain the phenomena of the immature lactogenesis. 


\section{REFERENCES}

Abou-Ziena, A.H. S.G.Hassan and A.M. Hamam, 2009. Trials for elevating adverse effect of heat stress in buffaloes with emphasis on metabolic status and fertility. J. Global vet., 3(1): 51-62.

Akers, R. M, 2006. Major advances associated with hormone and growth factor regulation of mammary growth and lactation in dairy cows. $\mathrm{J}$ Dairy Sci., 89: 1222-1234.

Berry, S. D. T. B. McFadden, R. E. Pearson, and R. M. Akers, 2001. A local increase in the mammary IGF-I: IGFBP-3 ratio mediates the mammogenic effects of estrogen and growth hormone. Domest. Anim. Endocrinol., 21: 39-53.

Cohick, W. S, 1998. Role of the insulin-like growth factors and their binding proteins in lactation. $J$. Dairy Sci., 81: 1769-1777.

FAOSTAT, 2013. FAO Statistics Devision, FAO, Rome, Italy.www.fao.org

Farouk, M. H, 2012. Milk production performance and some biochemical blood components in Egyptian buffaloes as affected by seasonal variation. Egyptian J. Anim. Prod. 49 (Suppl. Issue): 81-87.

Galal, S. and A. Elbeltagy, 2007 .Achievement of research in the field of buffalo production in Egypt. Anim. Prod. and Anim. Sci. World Wide. 177.

Gurmessa, J. and A. Melaku, 2012. Effect of lactation stage, pregnancy, parity and age on yield and major components of raw milk in bred cross Holstein- friesian cows, world J. Dairy Food Sci., 7 (2): 146-149.

Hadsell, D. L. N. M. Greenberg, J. M. Fligger, C. R. Baumrucker and J. M. Rosen, 1996. Targeted expression of des (1-3) human insulin-like growth factor $\mathrm{i}$ in transgenic mice influences mammary gland development and IGF-binding protein expression. Endocrinol., 137: 321-330.

Hassan F. A. Kahilo, M. Ateia, M. EL-kattawy and E. Fadl, 2014. Advanced studies on leptin and some biochemical parameters in lactating Buffaloes.World J. of Pharmaceut.Sci., 23213310.

Hauser, S. D. M. F. McGrath, R. J. Collier and G. G. Krivi, 1990. Cloning and in vivo expression of bovine growth hormone receptor mRNA.Mol Cell Endocrinol., 72: 187 - 200.

Keller, H.F.; B.P. Chew and R.E. Erb, 1977. Mammary transfer of hormones and constituents into secretions when cow were milked or secretions were sampled prepartum. J. Dairy Sci. 60: $546-556$.
Kleinberg, D. L, 1998. Role of IGF-I in normal mammary development.Breast Cancer Res. Treat., 47: 201-208.

Kumar, S. R. Mehla and R. Menna, 2011. Pre-andpostpartum managemental intervention through herbal feed supplement (Asparagus racemosus) and its effect on production and reproduction performance during supplementation and postsupplementation period in crossbred cows, Indian J. Anim. Sci., 81: 669-675.

Mahdi A, 2014. Effect of lactation stage and calve sex in some of milk components in Iraqi Riverine Buffalo. Kufa J. Vet. Med. Sci. Vol. 5 (1): 110114.

Metry, G. H. and K. A. Mourad, 1994. Lactation curves for first lactation Egyptian buffalo. J.Dairy Sci. 77: 1306-1314.

Mili. B, P. Sujata, K. Bharath and S. Mehtab, 2015. Changes in hormones of somatotropic axis during transition period in Murrah buffaloes (Bubalusbubalis) supplemented with vitamin E. J. Anim. Res., 5 (1): 27-30.

Miller, N. L. Dellecchi, G. petitclere, B. Wagner, G. Talbot and P. Lacasse, 2006. Effect of stage of lactation and parity on mammary gland cell renewal. Dairy Sci., 89 (12): 4669 - 4677.

NRC, 2001. Nutrient Requirements of Dairy Cattle, 7 th revised ed. National Academic Science, Washington, DC, USA.

Pawar,N. G. Ravi and N. Raman, 2013. Effect of heat stress on milk production and composition in Murrah buffaloes. J. Buffalo Sci., 98-102.

Ruan, W. C.B. Newman and D.L. Kleinberg, 1992. Intact and aminoterminally shortened forms of insulin-like growth factor I induce mammary gland differentiation and development. Dev. Biol., 89:10872-10876.

Seema H. and S. Quazi, 2014. Microbiologal and chemical analysis of buffalo milk supplies of beed district. J. Adv. Appl. Sci. Techn. 1:20-24.

SPSS. 2012. Statistical Package for Social Science. Release 21, copyright (C) SPSS. INC. Chicage, U.S.A.

Su, H. Y. and W. T. Cheng, 2004. Increased milk yield in transgenic mice expressing insulin like growth factor 1.AnimBiotechnol, 15: 9-19.

Surendra, P. K, Ram and S. Mahendra, 2012. Plasma hormones, metabolites, milk production and cholesterol levels in Murrah buffaloes fed with Asparagus racemosus in transition and postpartum period. Trop. Anim. Heal. Prod., 44:1827-1832. 
الدور الفسيولوجى لهرمونـات الأنسولين المشـابه لهرمون النمو والبرولاكتن فى الأداء الإتتاجى للجـاموس المصرى

منى الخثاب، أحمد رحيم، عمرو حيدر، على ربيع عبد الرحمن

قسم الإنتاج الحيوانس، كلية الزراعة، جامعة الفيوم

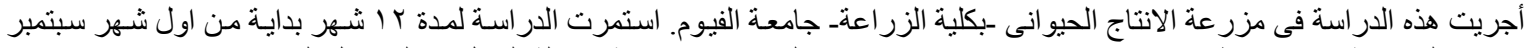

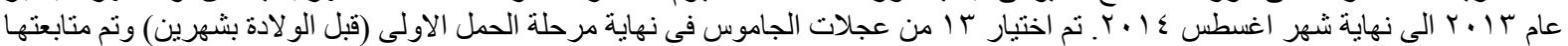

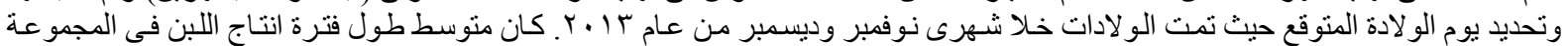

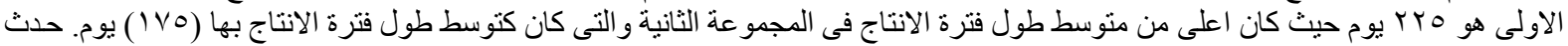

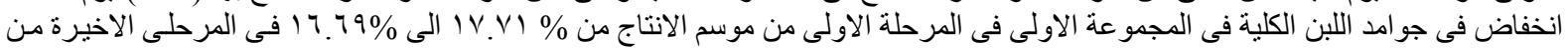

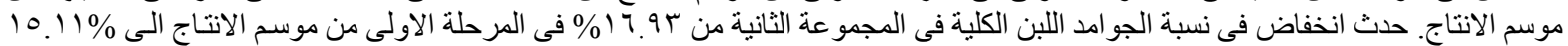

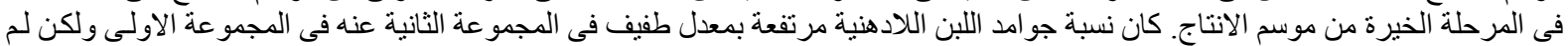

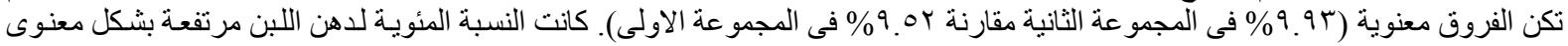

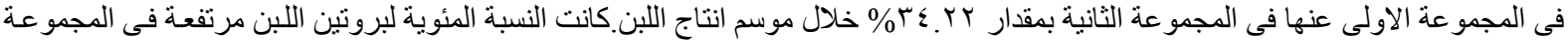

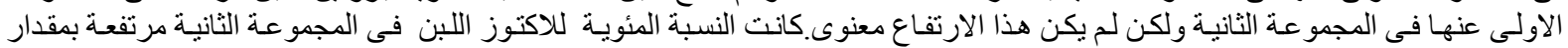

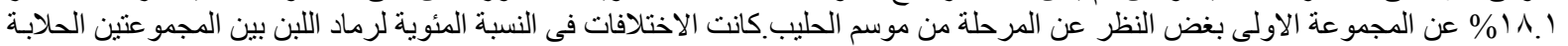

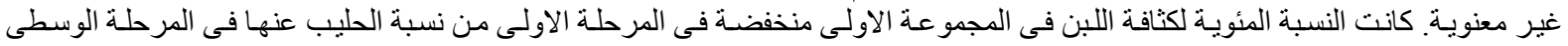

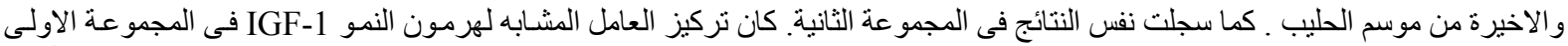

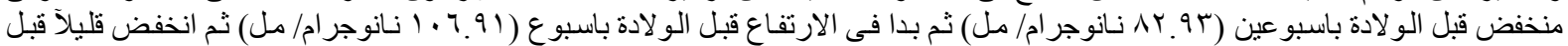

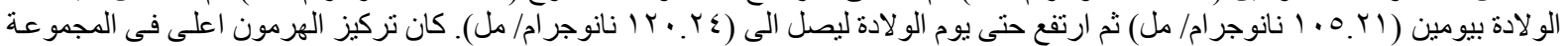

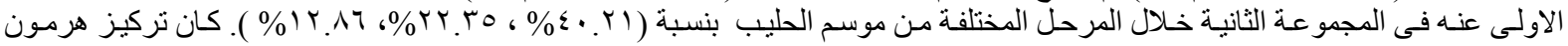

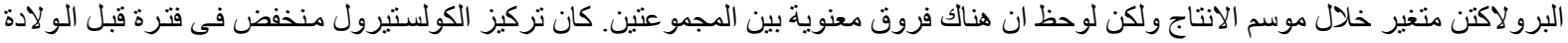

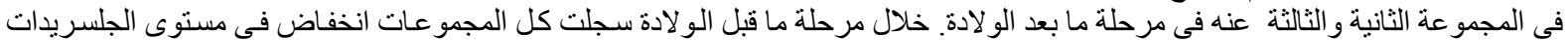
الثلاثية حتى يوم الو لادة. 